\title{
PENINGKATAN NILAI TAMBAH KONSUMSI PANGAN PRODUK MIE SAGU BAKSO IKAN LOKAL DESA BALIASE KECAMATAN MARAWOLA KABUPATEN SIGI
}

\author{
Syamsiar $^{1 *}$, Amalia Noviyanty ${ }^{2}$, Chitra Anggriani Salingkat $^{3}$, Sulmi $^{4}$ \\ ${ }^{1,2,3}$ Program Studi Agroteknologi, Fakultas Pertanian, Universitas Tadulako, \\ ${ }^{4}$ Program Studi Agribisnis, Fakultas Pertanian, Universitas Tadulako, \\ Jln. Soekarno-Hatta Km.9 Palu 94118 Sulawesi Tengah Indonesia \\ e-mail: ${ }^{1}$ syamsiarrachmat@yahoo.co.id, ${ }^{2}$ amalianoviyanti@ymail.com, \\ ${ }^{3}$ chitrasalingkat@yahoo.co.id, ${ }^{4}$ sulmisulmi@ymail.com
}

\begin{abstract}
ABSTRAK
Program pengabdian kepada masyarakat ini bertujuan untuk memanfaatkan bahan pangan lokal yang sudah ada melalui upaya diversifikasi pangan.Tepung sagu merupakan salah satu bahan pangan yang mengandung karbohidrat cukup tinggi yang digunakan oleh sebagian besar penduduk sebagai makanan sampingan yang berada di pedesaan bahkan di perkotaan, oleh sebab itu perlu tetap dikembangkan usaha sagu secara berkesinambungan sebagai bahan baku industri rumahtangga pangan dengan target khusus adalah memberikan peluang kerja bagi masyarakat untuk berwirausaha dengan memanfaatkan tepung sagu dan ikan basahsebagai bahan baku, sehingga memberikan nilai tambah dan memberikan pelatihan pembuatan produk mie sagu bakso ikan. Metode yang akan diterapkan yaitu metode pendekatan klasikal dan individual. Pendekatan klasikal dilakukan pada saat penyampaian materi di lapangan dalam bentuk demplot tentang teknik olahan produk tepung sagu bisa dimanfaatkan sebagai bahan dasar olahan mie sagu dan dipadukan dengan bakso ikan. Pendekatan individual dilakukan pada saat praktek di lapangan yang mana peserta yang telah diberi pendidikan dan pelatihan diharapkan dapat menyebarluaskan kepada anggota masyarakat lainnya. Hasil dari kegiatan ini adalah ibu-ibu PKK mampu memproduksi mie sagu dan bakso ikan secara mandiri sehingga dapat dikonsumsi untuk skala rumah tangga maupun skala industri untuk peningkatan nilai tambah konsumsi dan tambahan penghasilan.
\end{abstract}

Kata kunci : indutri, tepung sagu, mie sagu, bakso ikan

\section{Pendahuluan}

Tanaman sagu di Sulawesi Tengah merupakan tanaman yang tumbuh di daerah rawa yang berair tawar dan di daerah sepanjang aliran sungai, namun sampai saat ini belum ada tanaman sagu yang dibudidayakan secara intensif. Lahan yang sudah digunakan untuk tanaman sagu seluas 4.939 ha, dengan produksi pada Tahun 2012 sebanyak 680 ton (BPS Sulteng, 2013), dan Kabupaten sigi juga merupakan salah satu kabupaten yang berada di Provinsi Sulawesi Tengah, dan memiliki potensi sagu dan perikanan yang cukup besar.

Sagu (Metroxylon sagu) sebagai bahan lokal memiliki potensi yang besar untuk dikembangkan. Sagu mempunyai kemampuan memproduksi pati secara terusmenerus pada umur sekitar 10-15 tahun (Engelen dan Nurhafnita, 2018). Pati sagu sebagai produk utama dari tanaman sagu mempunyai prospek yang baik untuk dikembangkan sebagai produk pangan. Salah satu produk pangan yang potensial dari pati sagu adalah mie sagu (Yuliani, dkk., 2015). Tingginya peningkatan konsumsi dan kebutuhan mie akan meningkatkan volume impor gandum sebagai bahan baku utama dalam pembuatan tepung terigu, dimana merupakan bahan baku penting dalam pembuatan mie (Mulyadi, dkk., 2013). 
Bagi Indonesia yang bukan negara penghasil gandum, substitusi dengan tepung non-terigu untuk pembuatan makanan dapat menghemat devisa negara. Tingkat ketergantungan terhadap tepung terigu dapat dikurangi dengan subtitusi bahan lokal salah satunya adalah tepung sagu (Rinto, dkk., 2017).

Kondisi tersebut masih memberikan harapan yang cukup besar bagi pertumbuhan ekonomi di Sulawesi Tengah, terutama untuk usaha pengolahan makanan yang berasal dari sagu, bahkan untuk menciptakan nilai tambah dari tanaman sagu itu sendiri. Pada umumnya masyarakat baru memanfaatkan tepung sagu sebagai bahan baku lokal pembuatan makanan tradisional seperti : sinonggi, kapurung, bagea, mie dan lain-lain.

Ikan merupakan salah satu sumber protein hewani yang banyak dikonsumsi masyarakat karena relatif mudah diperoleh dan harganya terjangkau. Perhatian terhadap ikan berharga murah dan pemprosesannya menjadi bahan makanan yang berharga lebih mahal merupakan hal yang diperlukan oleh negara -negara yang mempunyai sumber perikanan yang besar, terutama di Indonesia. Banyak jenis ikan yang dikembangkan di Indonesia, meliputi perikanan air tawar, air laut dan air payau (Mareta, 2011). Diversifikasi pengolahan komoditi perikanan agar mampu memanfaatkan sumber daya perikanan menjadi optimal dan meningkatkan minat masyarakat untuk mengkonsumsi ikan, salah satunya dengan pembuatan bakso ikan (Arinsarani, 2018)

Bahan pangan lokal sangat penting untuk dikembangkan karena dapat meningkatkan ekonomi keluarga sehingga perlu adanya pendekatan kepada masyarakat agar tetap dilestarikan dan juga mempunyai prospek untuk dikembangkan menujuh ketahanan pangan yang berkelanjutan. Sehingga bisa memiliki nilai tambah konsumsi pangan lokal berupa produk mie sagu bakso ikan yang faedahnya meningkat, sehingga nilai rupiahnya juga meningkat dan terjadi peningkatan pendapatan yang turut dinikmati oleh anggota keluarganya.

\section{Perumusan Masalah}

Adapun permasalahan yang dihadapi oleh ibu-ibu PKK Desa Baliase sebagai mitra dalam pengabdian ini adalah sebagai berikut:

1. Ibu-ibu PKK belum pernah mengolah tepung sagu untuk dijadikan sebagai bahan utama dalam pembuatan mie dari tepung sagu.

2. Ibu-ibu PKK belum begitu tertarik untuk peningkatan nilai tambah produk sagu dan bakso ikan. Umumnya hanya dikonsumsi untuk kebutuhan rumah tangga sendiri

\section{Metode Penelitian}

Metode yang digunakan dalam program pengabdian masyarakat ini adalah pendidikan dan pelatihan dengan menggunakan metode penyuluhan, bimbingan teknis dan pelatihan, serta pembinaan dan evaluasi yang dilakukan dengan pendekatan partisipatif. Metode ini memposisikan ibu-ibu rumah tangga sebagai penerima pengetahuan, pemahaman, dan keterampilan yang berkenaan dengan diversifikasi olahan sagu dan ikan basah. Penggunaan metode partisipatif dimaksudkan untuk melibatkan secara aktif ibu-ibu PKK di desa Baliase.

\section{Penyuluhan}

Materi penyuluhan yang disampaikan terdiri atas aspek teknis dan sosial ekonomi, seperti :

(a) Diversifikasi olahan pangan dari sagu serta prospeknya

(b) Teknologi pengolahan tepung sagu menjadi mie

(c) Teknologi pengolahan bakso ikan

(d) Pemasaran hasil olahan yaitu mie sagu dan bakso ikan 


\section{Bimbingan Teknis dan Pelatihan}

Bimbingan teknis dan pelatihan yang dilakukan berupa teknik pengolahan tepung sagu menjadi mie dan teknik pembuatan bakso ikan. Bimbingan dan pelatihan pengolahan mie sagu dan bakso ikan bertujuan untuk melatih ibu-ibu PKK dalam membuat mie sagu dan bakso ikan dan mereka dapat mengaplikasikan ilmu yang diperoleh untuk keperluan konsumsi rumah tangga sendiri maupun untuk memperoleh penghasilan tambahan. Pada kegiatan ini ibu-ibu PKK didampingi langsung oleh tim pengabdi untuk memastikan kegiatan berjalan sesuai dengan rencana.

3. Pembinaan dan Evaluasi

Pembinaan kepada ibu-ibu PKK dilakukan dalam upaya meningkatkan keterampilannya yang berkaitan dengan teknologi pengolahan mie sagu dan bakso ikan dan melakukan evaluasi untuk melihat sejauh mana kelompok sasaran melaksanakan teknologi yang diusulkan dalam program pengabdian kepada masyarakat ini.

\section{Hasil dan Pembahasan :}

\section{Hasil}

Kegiatan ini merupakan Program Pengabdian Kepada Masyarakat yang dilaksanakan pada ibu-ibu PKK yang didukung oleh dana BLU Fakultas Pertanian Universitas Tadulako Tahun 2019. Hasil program pengabdian pada masyarakat dapat dilihat pada Tabel 1 .

Tabel 1. Hasil kegiatan program pengabdian tahun 2019.

\begin{tabular}{llll}
\hline \multicolumn{1}{l}{ Uraian Kegiatan } & \multicolumn{2}{c}{ Capaian } \\
\hline $\begin{array}{l}\text { Khalayak } \\
\text { Sasaran }\end{array}$ & & \\
\hline - Mitra & $:$ & Ibu-ibu PKK \\
Kegiatan & & & \\
\hline - Jarak PT ke & $:$ & $15 \mathrm{~km}$ \\
Lokasi Mitra & & & \\
\hline - Jumlah & $:$ & 20 orang & \\
Anggota Mitra & & & \\
\hline$\bullet \quad$ Persoalan & $:$ & Belum & terlalu \\
\hline
\end{tabular}

\begin{tabular}{|c|c|c|}
\hline Mitra & & $\begin{array}{l}\text { mengetahui } \\
\text { pengolahan mie dari } \\
\text { sagu dan pembuatan } \\
\text { bakso ikan yang baik }\end{array}$ \\
\hline $\begin{array}{l}\text { - Status Sosial } \\
\text { Mitra }\end{array}$ & : & Ibu PKK \\
\hline $\begin{array}{l}\text { - Kegiatan } \\
\text { Mitra }\end{array}$ & $:$ & $\begin{array}{l}\text { Ibu Rumah Tangga } \\
\text { (IRT) }\end{array}$ \\
\hline $\begin{array}{ll}\text { Program } & \text { dan } \\
\text { Identitas } & \\
\text { Pelaksana } & \\
\end{array}$ & & \\
\hline $\begin{array}{l}\text { - } \quad \text { Program } \\
\text { Pendampingan }\end{array}$ & : & $\begin{array}{l}\text { Dana BLU Fakultas } \\
\text { Pertanian Universitas } \\
\text { Tadulako Tahun } 2019\end{array}$ \\
\hline - Jumlah Dosen & $:$ & 4 orang \\
\hline $\begin{array}{l}-\quad \text { Jumlah } \\
\text { Mahasiswa }\end{array}$ & : & $\begin{array}{l}4 \text { orang (Mahasiswa } \\
\text { KKN) }\end{array}$ \\
\hline $\begin{array}{l}\text { - Gelar } \\
\text { Akademik Tim }\end{array}$ & : & S2 4 orang \\
\hline $\begin{array}{l}\text { - Prodi/Fakultas } \\
\text { /Sekolah }\end{array}$ & : & $\begin{array}{l}\text { Agroteknologi dan } \\
\text { Agribisnis/Pertanian/ } \\
\text { Universitas Tadulako }\end{array}$ \\
\hline $\begin{array}{l}\text { Metodologi } \\
\text { Pendekatan } \\
\end{array}$ & & \\
\hline $\begin{array}{l}\text { - Metode } \\
\text { Pelaksanaan } \\
\text { Kegiatan }\end{array}$ & & $\begin{array}{ll}\text { - } & \text { Penyuluhan } \\
\text { - Pelatihan/demons } & \text { trasi tentang } \\
\text { proses teknologi } \\
\text { pengolahan mie } \\
\text { dari sagu dan } \\
\text { pengolahan bakso } \\
\text { dari ikan } \\
\text { - Pendampingan } \\
\end{array}$ \\
\hline
\end{tabular}

- Waktu Efektif : 3 bulan

Pelaksanaan

Kegiatan

Pendampingan/E

valuasi Kegiatan

- Keberhasilan : Berhasil

Indikator

Keberhasilan

- Keberlanjutan : Berlanjut produk mie

Kegiatan di Mitra sagu dan bakso ikan

\section{Likuiditas Dana}

Program

- Tahap : Mendukung Kegiatan

Pencairan Dana di Lapangan

- Jumlah Dana : Diterima 70\% (Tahap

I) 
Diterima 30\% (Tahap II)

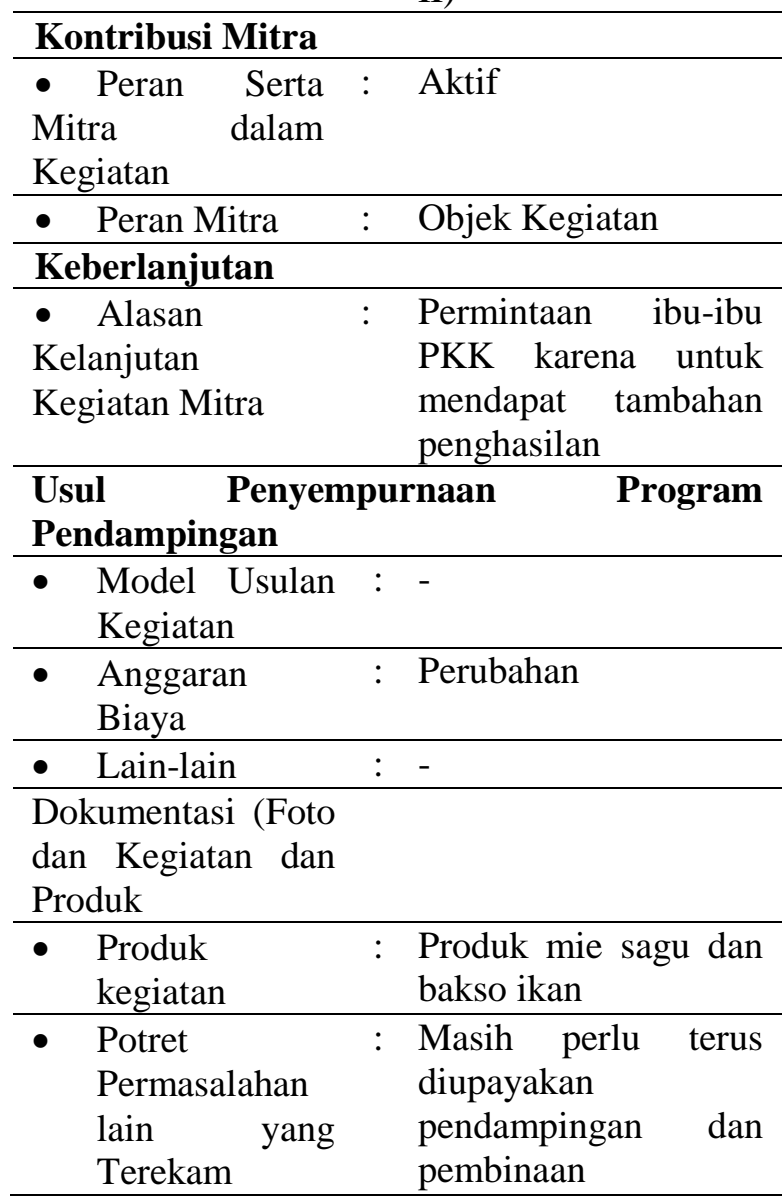

Program yang telah dijalankan, berupa:

\section{a. Penyuluhan}

Penyuluhan dilakukan untuk memberikan pemahaman kepada ibu-ibu PKK tentang beberapa diversifikasi olahan pangan sagu dan prospeknya serta penyuluhan tentang teknologi pengolahan tepung sagu menjadi mie dan pengolahan bakso ikan.

Metode pendekatan yang digunakan dalam penyuluhan ini adalah metode ceramah yang dilakukan oleh pemateri dalam hal ini oleh tim Pengabdi dan metode diskusi (tanya-jawab) oleh ibu-ibu PKK, hal ini bertujuan untuk memberikan pemahaman kepada ibu-ibu PKK tentang kegiatan yang akan dilaksanakan serta memberikan informasi awal tentang pemahaman ibu-ibu
PKK tentang pengolahan mie sagu dan bakso ikan.

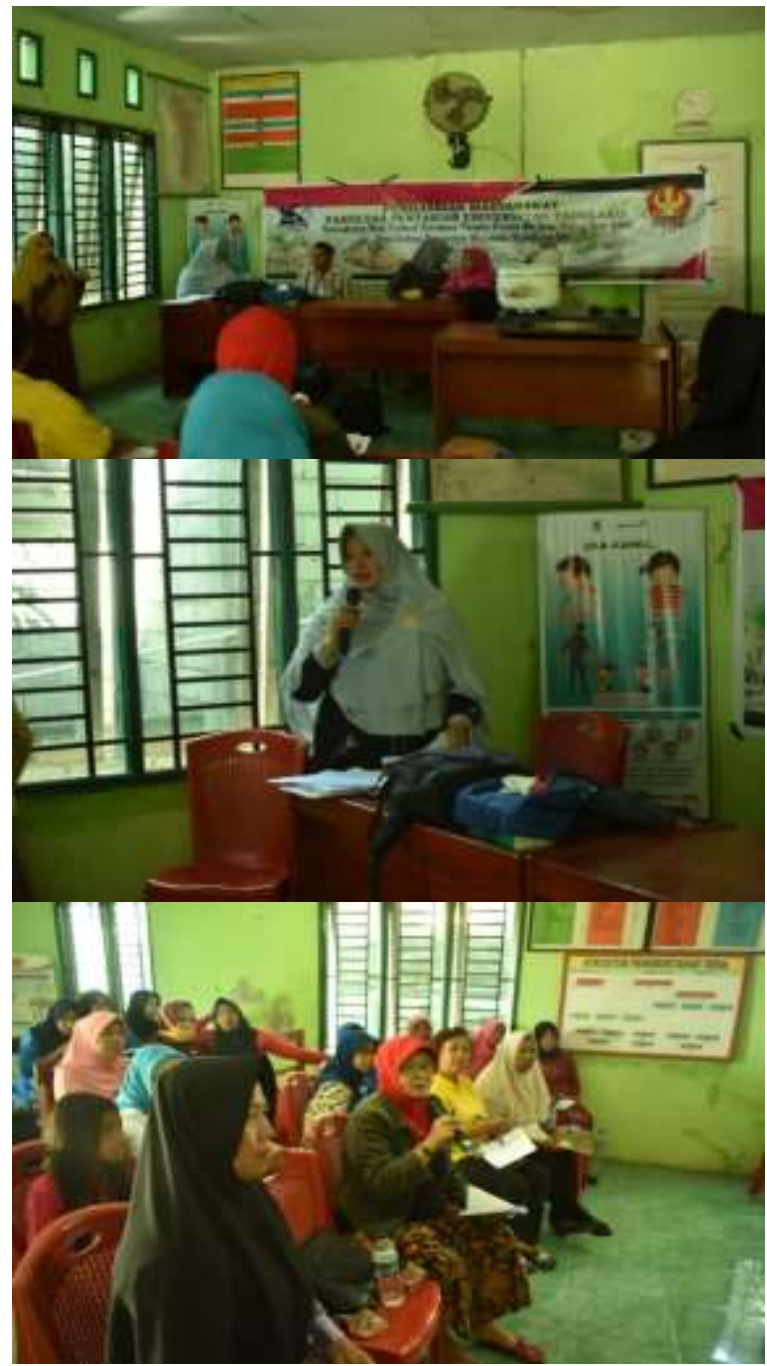

Gambar 1. Tim Pengabdi sedang Melakukan Penyuluhan

\section{b. Bimbingan Teknis dan Pelatihan}

Bimbingan teknis dan pelatihan ini dihadiri olehibu-ibu PKK di Desa Baliase, kepala desa dan mahasiswa KKN yang diundang untuk menyaksikan kegiatan tersebut. Kegiatan ini diawali dengan dengan pemaparan singkat berupa video cara pembuatan mie sagu dan bakso ikan. Setelah pemaparan singkat tersbut, dilanjutkan dengan demplot pembuatan mie sagu dan bakso ikan. 


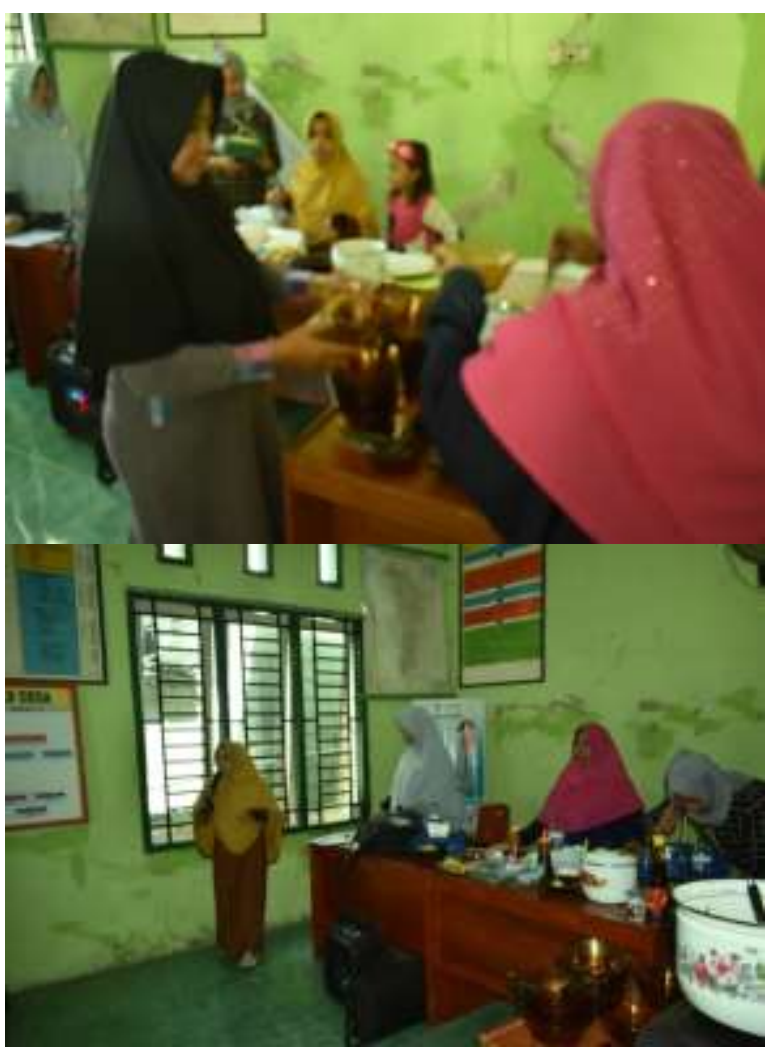

Gambar 2. Tim Pengabdi melakukan praktik pembuatan mie sagu dan bakso ikan bersama ibu-ibu PKK.

\section{c. Pembinaan dan Evaluasi}

Setelah dilakukan penyuluhan, bimbingan teknis dan pelatihan, diharapkan ibu-ibu PKK di Desa Baliase dapat memahami dan mau menyebarkan dan berbagi informasi dan ilmu yang diperoleh kepada keluarga, tetangga dan orang disekitarnya.

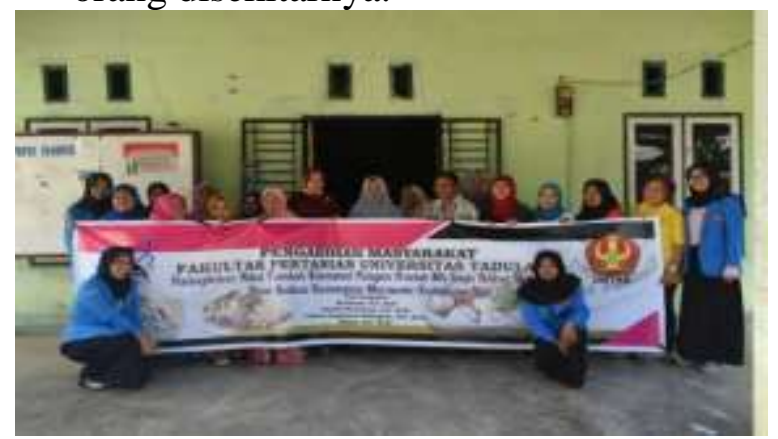

Gambar 3. Foto bersama dengan tim pengabdi dengan ibu-ibu PKK dan Mahasiswa KKN serta anggota tim pengabdi sedang melakukan evaluasi pembinaan kegiatan pengabdian.

\section{Pembahasan}

Khalayak sasaran kegiatan Program Pengabdian Kepada Masyarakat ini adalah ibu-ibu PKK yang berlokasi di Desa Baliase Kecamatan Marawola Kabupaten Sigi Provinsi Sulawesi Tengah dengan jarak Perguruan Tinggi ke lokasi mitra $15 \mathrm{~km}$ dengan waktu tempuh \pm 30 menit. Kegiatan ibu-ibu PKK ini adalah sebagian besar sebagai Ibu Rumah Tangga. Dalam program kegiatan pengabdian ini difokuskan untuk pengolahan mie dari sagu dan bakso dari ikan yang selanjutnya produk mie sagu dan bakso ikan ini dapat dikonsumsi sendiri dalam skala rumah tangga ataupun lebih jauh dapat dimanfaatkan untuk menambah penghasilan keluarga jika dijadikan lahan bisnis secara konsvensional.

Kegiatan ini merupakan Program Pengabdian kepada Masyarakat yang didanai oleh dana BLU Fakultas Pertanian Universitas Tadulako melalui program kerja Fakultas Pertanian Tahun Anggaran 2019 dengan tim pengabdi yang terdiri dari empat (4) orang dosen yang bergelar akademik S2, satu orang teknisi dan dua (2) orang mahasiswa sebagai tim asisten pengabdi dan supporting kegiatan ini. Pelaksanaan kegiatan dikoordinasikan dengan Kepala Desa dan ibu-ibu PKK. Metode pendekatan yang digunakan meliputi penyuluhan, pelatihan/demonstrasi proses teknologi pengolahan mie dari sagu dan teknologi pembuatan bakso dari ikan selain itu juga dilakukan pendampingan, monitoring dan evaluasi. Materi penyuluhan yang disampaikan adalah teknologi pengolahan tepung sagu menjadi mie serta teknologi pengolahan bakso dari ikan.

Hasil program pengabdian kepada masyarakat ini mampu menambah pengetahuan dan ketrampilan ibu-ibu PKK desa baliase terkait dengan pengolahan tepung sagu menjadi produk olahan yaitu mie dan pengolahan bakso dari ikan. Pendampingan dalam pengabdian ini 
dilakukan secara berkelanjutan dan periodik dengan tujuan memantau perkembangan pengelolaan dan pengolahan mie dan bakso ikan di lokasi mitra tetap terus berkelanjutan dan diaplikasikan. Selain itu juga dilakukan evaluasi secara periodik untuk ketrampilan penguasaan teknologi pengolahan tepung sagu menjadi mie dan pengolahan bakso ikan sehingga diharapkan ibu-ibu PKK di Desa Baliase mau berbagi informasi yang diperoleh kepada keluarga, tetangga dan orang disekitarnya sehingga program pengabdian terus berkelanjutan dan pada akhirnya terbentuk ibu-ibu PKK terutama di Desa Baliase Kecamatan Marawola Kabupaten Sigi Provinsi Sulawesi Tengah mampu melakukan usaha mandiri dan berbasis agribisnis dari produk olahan mie sagu dan bakso ikan.

Untuk keberlanjutan program pengabdian ini maka diperlukan peran aktif ibu-ibu PKK di lokasi mitra untuk tetap terus meningkatkan produksi produk olahan mie sagu dan bakso ikan dari segi kuantitas sampai tahap pemasaran dengan tetap memperhatikan kualitas produk olahan yang dihasilkan. Di samping itu, program pengabdian ini masih perlu ditingkatkan dananya yang harus dilakukan secara berkelanjutan dan mencari sumber pendanaan yang lain diantaranya dari pihak pemerintah dan swasta untuk menunjang keberlanjutan program pengabdian ini.

\section{Kesimpulan}

Hasil kegiatan pengabdian masyarakat ini telah berhasil mentransfer teknologi pengolahan tepung sagu menjadi mie dan pengolahan bakso ikan kepada ibu-ibu PKK Desa Baliase dan ibu-ibu PKK memiliki keterampilan dalam pengolahan tepung sagung menjadi mie dan pengolahan bakso ikan, sehingga hasil program pengabdian ini dapat meningkatkan nilai tambah konsumsi sagu dan ikan dan meningkatkan pendapatan bagi ibu-ibu PKK.

\section{Daftar Pustaka}

Arinsarani D. 2018. Pengaruh Jenis Ikan Dan Jenis Pengenyal Terhadap Kualitas Bakso Ikan. Skripsi S-1. Program Studi Teknologi Pangan, Fakultas Teknik, Universitas Pasundan, Bandung.

BPS Provinsi Sulawesi Tengah. 2013. Sulawesi Tengah Dalam Angka. Badan Pusat Statistik Provinsi Sulawesi Tengah, Palu.

Engelen A., Nurhafnita. 2018. Karakteristik Mi Sagu (Metroxylon sagu) Kering Dengan Penambahan Sari Kunyit (Curcuma domestica) Sebagai Pewarna Alami. JTech, 6(2): 49-54.

Mareta, D. T. dan S. N. Awami. 2011. Pengawetan Ikan Bawal Dengan Pengasapan Dan Pemanggangan. Jurnal Ilmu-Ilmu Pertanian. 7:37-47.

Mulyadi AF, Wijana, Susingsih, Dewi IA dan Putri WI. 2014. Karakteristik Orgenoleptik Produk Mie Kering Ubi Jalar Kuning (Ipomoea batatas) Kajian Penambahan Telur dan CMC. Jurnal Teknologi Pertanian, 15(1): 25-36.

Rinto, Tamrin, Muzuni. 2017. Pengaruh Substitusi Tepung Sagu (Metroxylon sp.) Terfermentasi Dan Penambahan Putih Telur Terhadap Penilaian Sensorik Dan Nilai Gizi Mie Kering. Jurnal Sains dan Teknologi Pangan, 2(3): 631-640.

Yuliani H., N. D. Yuliana., S. Budijanto. 2015. Formulasi Mi Kering Sagu dengan Subtitusi Tepung Kacang Hijau. Agritech, 35(4): 387-395. 